Original Article

\title{
Maximal respiratory pressure in healthy Japanese children
}

\author{
Miki Tagami, PT, PhD ${ }^{1)^{*}}$, Yukako Okuno, PT, PhD ${ }^{2)}$, Tadamitsu Matsuda, PT, $\mathrm{PhD}^{1)}$, \\ Kenta Kawamura, PT $^{3)}$, Ryosuke Shoji, PT $^{4}$, Kazuhide Tomita, PT, PhD $^{2,3}$ ) \\ 1) Department of Physical Therapy, Uekusa Gakuen University: 1639-3 Ogura-cho, Wakaba-ku, \\ Chiba-city, Chiba 264-0007, Japan \\ 2) Department of Physical Therapy, Ibaraki Prefectural University of Health Sciences, Japan \\ 3) Graduate School of Health Sciences, Ibaraki Prefectural University of Health Sciences, Japan \\ 4) Department of Physical Therapy, Ibaraki Prefectural University of Health Hospital, Japan
}

\begin{abstract}
Purpose] Normal values for respiratory muscle pressures during development in Japanese children have not been reported. The purpose of this study was to investigate respiratory muscle pressures in Japanese children aged 3-12 years. [Subjects and Methods] We measured respiratory muscle pressure values using a manovacuometer without a nose clip, with subjects in a sitting position. Data were collected for ages 3-6 (Group I: 68 subjects), 7-9 (Group II: 86 subjects), and 10-12 (Group III: 64 subjects) years. [Results] The values for respiratory muscle pressures in children were significantly higher with age in both sexes, and were higher in boys than in girls. Correlation coefficients were significant at values of 0.279 to 0.471 for each gender relationship between maximal respiratory pressure and age, height, and weight, respectively. [Conclusion] In this study, we showed pediatric respiratory muscle pressure reference value for each age. In the present study, values for respiratory muscle pressures were lower than Brazilian studies. This suggests that differences in respiratory muscle pressures vary with ethnicity.

Key words: Respiratory muscle pressures, Japanese children, Correlated factors
\end{abstract}

(This article was submitted Aug. 5, 2016, and was accepted Dec. 7, 2016)

\section{INTRODUCTION}

Respiratory muscle pressures are the maximum values of the negative and positive intraoral pressures generated by respiratory resistance effort, and are described as maximal inspiratory pressure (PImax) and maximal expiratory pressure (PEmax), respectively ${ }^{1}$. In pediatrics, these values are used to quantitatively assess muscle weakness and/or the severity of neuromuscular disease, asthma, cystic fibrosis, and impairment after thoracic surgery. The values have also been used for load setting in respiratory muscle training. Previous studies reported normal values for respiratory muscle pressures in children $^{2-9)}$. Johan ${ }^{10)}$ reported significant differences in respiratory function between Western and Asian populations. In Japan, previous studies only investigated respiratory muscle pressures in adults ${ }^{11)}$. Normal values for respiratory muscle pressures during development in children have not been reported.

The purpose of this study was to determine respiratory muscle pressures in healthy Japanese children aged 3 to 12 years old. These data would be used to determine predictive equations for respiratory muscle pressures throughout childhood.

\section{SUBJECTS AND METHODS}

The subjects included 220 children who participated in a physical fitness festival hosted by local government. This study

*Corresponding author. Miki Tagami (E-mail: m-tagami@uekusa.ac.jp)

(C2017 The Society of Physical Therapy Science. Published by IPEC Inc.

This is an open-access article distributed under the terms of the Creative Commons Attribution Non-Commercial No Derivatives (by-nc-nd) License $<$ http://creativecommons.org/licenses/by-nc-nd/4.0/>. 
Table 1. Characterization of the sample according to gender and age $(\mathrm{N}=218)$

\begin{tabular}{|c|c|c|c|c|c|c|}
\hline & & Boys & & & Girls & \\
\hline Group & I (31) & II (53) & III (21) & I (37) & II (33) & III (43) \\
\hline Age (years) & $5.4 \pm 0.9$ & $8.0 \pm 0.7$ & $10.9 \pm 0.7$ & $4.9 \pm 1.1$ & $8.1 \pm 0.8$ & $10.7 \pm 0.7$ \\
\hline Hight $(\mathrm{cm})$ & $113.2 \pm 8.0$ & $128.4 \pm 6.4$ & $133.0 \pm 28.4$ & $109.8 \pm 7.5$ & $128.5 \pm 8.3$ & $143.6 \pm 7.4$ \\
\hline Weight (kg) & $19.2 \pm 2.5$ & $26.5 \pm 5.0$ & $33.5 \pm 4.9$ & $18.0 \pm 2.8$ & $25.4 \pm 4.4$ & $34.3 \pm 6.8$ \\
\hline
\end{tabular}

Values are mean \pm SE. Group I: 3-6 years, Group II: 7-9 years, Group III: 10-12 years (number of individuals)

Table 2. Values of respiratory muscle pressures according to gender and age $(\mathrm{N}=218)\left(\right.$ unit: $\left.\mathrm{cmH}_{2} \mathrm{O}\right)$

\begin{tabular}{lcccccc}
\hline & \multicolumn{3}{c}{ Boys } & \multicolumn{3}{c}{ Girls } \\
\hline Group & I & II & III & I & II & III \\
\hline PImax & $40.5 \pm 19.0$ & $53.8 \pm 19.6^{\mathrm{a}}$ & $70.3 \pm 20.5^{\mathrm{b}, \mathrm{c}}$ & $38.1 \pm 15.0$ & $54.4 \pm 14.0^{\mathrm{a}}$ & $57.2 \pm 21.2^{\mathrm{b}}$ \\
PEmax & $45.1 \pm 13.5$ & $56.6 \pm 14.6^{\mathrm{a}}$ & $63.1 \pm 16.4^{\mathrm{b}}$ & $39.4 \pm 14.5$ & $52.7 \pm 16.0^{\mathrm{a}}$ & $55.7 \pm 17.8^{\mathrm{b}}$ \\
\hline
\end{tabular}

Values are expressed as mean \pm SE. Group I: 3-6 years, Group II: 7-9 years, Group III: 10-12 years (number of individuals) PImax: Pressure Inspiratory max; PEmas: Pressure Expiratory max. Significant difference $(p<0.001)$ for PImax and PEmax compared with other age groups. ${ }^{\mathrm{a}} \mathrm{Group}$ I vs. II, ${ }^{\mathrm{b}} \mathrm{Group}$ I vs. III, ${ }^{\mathrm{c}}$ Group II vs. III

followed the principles of the Declaration of Helsinki, and all children and parents gave informed consent, following verbal explanation of the research content. A designated examiner measured respiratory muscle pressures using a manovacuometer (HI-801, CHEST, Tokyo, Japan). A self-reported questionnaire was used to obtain a history of asthma and respiratory symptoms (cough, sore throat) before measurement of maximal respiratory muscle pressures. Among 220 participants, two people were excluded because they had respiratory diseases and common cold symptoms. To ensure understanding, an examiner demonstrated the measurement technique, and then asked the subject to practice without using the mouthpiece, followed by performance of the test. The measurements were taken with the subject in a sitting position without use of a nose clip. We instructed subjects to rapidly breathe in and out as hard as possible, with the trunk held still. To prevent air leakage, they were instructed to firmly hold the mouthpiece between their lips. An examiner offered assistance as needed. The examiner repeated the test 2-3 times while monitoring the waveform on the spirometer in order to obtain accurate data. The examiner also noted whether the subject understood the measurement method.

The maximum values were used for respiratory pressures. Data were collected for ages 3-6 (Group I), 7-9 (Group II), and 10-12 (Group III). One-way analysis of variance (ANOVA) was used to compare data for maximal respiratory pressures (PImax and PEmax) in the 3 groups. Multiple regression analysis was performed to assess the contributions of age, height, and weight to the differences in PImax and PEmax. Height and weight have heard from parents. The data were statistically processed using SPSS (IBM, for Windows Statistics version 20.0). Statistical significance was defined as $\mathrm{p}<0.05$.

\section{RESULTS}

We analyzed 218 healthy subjects aged 3-12 (105 boys and 113 girls). Table 1 shows the means and standard deviations for height and weight for each of the 3 groups.

Table 2 compares the mean PImax and PEmax values. For PImax in boys, the mean difference $\left(\mathrm{cm}_{2} \mathrm{O}\right)$ in Group I was $40.5 \pm 19.0$; in Group II, $53.8 \pm 19.6$; and in Group III, $70.3 \pm 20.5(\mathrm{p}<0.001$, between all groups). For PImax in girls, the mean difference in Group I was 38.1 \pm 15.2; in Group II, $54.4 \pm 14.0$; and in Group III, $57.2 \pm 21.2$ ( $\mathrm{p}<0.01$ between I and II, and $\mathrm{p}<0.001$ between I and III). PImax values increased with age for both gender.

For PEmax in boys, the mean difference in Group I was 45.1 \pm 13.5 ; in Group II, $55.6 \pm 14.6$; and in Group III, $63.1 \pm$ $16.4(\mathrm{p}<0.01$ between Groups I and II, and Group III). For PEmax in girls, the mean difference in group I was 39.4 \pm 14.5 ; in Group II, $52.7 \pm 16.0$; and in Group III, $55.7 \pm 17.8$ ( $\mathrm{p}<0.01$, between Groups I and II, and Group III). PEmax values increased with age for both gender. PEmax showed higher than in GroupI and other age-groups. PImax and PEmax in boys showed higher than in girls.

Our measurements were correctly performed because the measurement deviation of the Group I has no difference with other age-groups, although it was expected to be difficult to measure in preschool children (Group I).

Maximal respiratory pressure showed positive correlations between age, height, weight $(r=0.279-0.471)($ Table 3$)$. We calculated the regression equations for prediction of PImax and PEmax for each gender, as follows. 
Table 3. Pearson's correlation coefficient for each gender relationship between maximal respiratory pressure and age, height, weight

\begin{tabular}{lcccccc}
\hline & \multicolumn{3}{c}{ Boys } & \multicolumn{3}{c}{ Girls } \\
\hline & Age & Height & Weight & Age & Height & Weight \\
\hline PImax $\left(\mathrm{cmH}_{2} \mathrm{O}\right)$ & $0.459^{*}$ & $0.421^{*}$ & $0.361^{*}$ & $0.399^{*}$ & $0.415^{*}$ & $0.401^{*}$ \\
PEmax $\left(\mathrm{cmH}_{2} \mathrm{O}\right)$ & $0.333^{*}$ & $0.316^{*}$ & $0.279^{*}$ & $0.434^{*}$ & $0.471^{*}$ & $0.342^{*}$ \\
\hline
\end{tabular}

${ }^{*} \mathrm{p}<0.001$. PImax: Pressure Inspiratory max; PEmax: Pressure Expiratory max

PImax $\left(\mathrm{cmH}_{2} \mathrm{O}\right)$ :

$$
\begin{aligned}
& \text { Boys }=9.080+5.189 \times \text { age }(\text { years })+0.039 \times \text { height }(\mathrm{cm})-0.053 \times \text { weight }(\mathrm{kg})\left(\mathrm{R}^{2}=0.219, \mathrm{p}<0.001\right) \\
& \text { Girls }=4.953+0.957 \times \text { age }(\text { years })+0.244 \times \text { height }(\mathrm{cm})+0.234 \times \text { weight }(\mathrm{kg})\left(\mathrm{R}^{2}=0.155, \mathrm{p}<0.001\right)
\end{aligned}
$$

PEmax $\left(\mathrm{cmH}_{2} \mathrm{O}\right)$ :

$$
\begin{aligned}
& \text { Boys }=39.570+2.817 \times \text { age }(\text { years })-0.096 \times \text { height }(\mathrm{cm})-0.189 \times \text { weight }(\mathrm{kg})\left(\mathrm{R}^{2}=0.131, \mathrm{p}<0.001\right) \\
& \text { Girls }=-43.890-0.003 \times \text { age }(\text { years })+0.916 \times \text { height }(\mathrm{cm})-0.913 \times \text { weight }(\mathrm{kg})\left(\mathrm{R}^{2}=0.219, \mathrm{p}<0.001\right)
\end{aligned}
$$

\section{DISCUSSION}

Respiratory muscle pressures are used to evaluate lung and neuromuscular disease and to plan a respiratory muscle training program. However, reference values for respiratory muscle pressures have not been reported for Japanese children. In this study, we investigated the respiratory muscle pressures in healthy children aged 3-12 years. It was found that respiratory muscle pressures in healthy children increased with age in both genders, and was higher in boys than in girls. Furthermore, the values in Japanese children were lower than those reported in other countries $2,3,7,9,16$ ).

Previous studies also reported that respiratory muscle pressures in healthy children increased with age $\mathrm{e}^{2,3,6,7,12)}$. This study classified the children surveyed into 3 groups by age. PImax in boys were significantly different between groups ( $p<0.001)$. PEmax in boys in Groups I and II were significantly different from those in Group III $(\mathrm{p}<0.001)$. In contrast, PImax and PEmax in girls in Groups I and II were significantly different from those in Group III ( $<<0.001)$. Paulo et al. ${ }^{9}$ ) reported that respiratory muscle pressures in preschool children exhibited particularly low values, and the present study showed similar results. Wilson et al. ${ }^{6}$ demonstrated that age had predictive capability for expiratory muscle pressures. Our results indicated a correlation between age and respiratory muscle pressures in children.

Joao et al. ${ }^{9)}$ reported that gender is an important independent factor in prediction of respiratory muscle pressures. Several studies $^{6,7,9)}$ reported that respiratory muscle pressure values were higher in boys than in girls, and our results were similar.

Joao et al. ${ }^{9)}$ investigated respiratory muscle pressures in children aged 3-12 in Brazil, the same ages as the subjects in our investigation. Our results for respiratory muscle pressures showed lower values of $46-47 \%$ in boys and $58-64 \%$ in girls, compared to the results of Joao et $\mathrm{al}^{9}{ }^{9}$. Some reports investigated the relationship between respiratory muscle pressures, height, and weight ${ }^{6,7)}$. Wilson et al. ${ }^{6}$ reported that body weight, height, and age in children were independent variables for prediction of respiratory muscle pressures. Domenech et al. reported that height and weight are related to expiratory muscle pressures in boys, and that age is related to inspiratory muscle pressures in girls. The children in our study were about $10 \%$ shorter and weighed about $20 \%$ less than those in the report by Joao et $\mathrm{al}^{9}$.

Johan et al. ${ }^{10)}$ reported ethnic differences in respiratory muscle pressures, even among Asians, and Asians had generally lower values than Canadians. Evans reported that ethnicity strongly affects respiratory muscle pressures ${ }^{14)}$. The physical attributes of children in this study were average for age, based on those reported by the Japanese Ministry of Health, Labour and Welfare ${ }^{13)}$. Therefore, the low value for respiratory muscle pressures could have reflected ethnic differences.

A limitation of the present study is the lack of a follow-up evaluation of respiratory muscle pressures, which have been found to be elevated in young people in a 1-year-follow-up survey ${ }^{15)}$. Although respiratory muscle pressures in young people are correlated with the amount of physical activity and competitive sports ${ }^{15}$, we did not investigate these factors.

In conclusion, this is the first report of respiratory muscle pressures in Japanese children aged 3-12 years. Respiratory muscle pressures increase with age, and are higher in boys than in girls. Furthermore, height, weight, age and gender were correlated with respiratory muscle pressures in children. The respiratory muscle pressures in the present study were lower than those in previous studies. 


\section{REFERENCES}

1) Cook CD, Mead J, Orzalesi MM: Static volume-pressure characteristics of the respiratory system during maximal efforts. J Appl Physiol, 1964, 19: 1016-1022. [Medline]

2) Gaultier C, Zinman R: Maximal static pressures in healthy children. Respir Physiol, 1983, 51: 45-61. [Medline] [CrossRef]

3) Szeinberg A, Marcotte JE, Roizin H, et al.: Normal values of maximal inspiratory and expiratory pressures with a portable apparatus in children, adolescents, and young adults. Pediatr Pulmonol, 1987, 3: 255-258. [Medline] [CrossRef]

4) Smyth RJ, Chapman KR, Rebuck AS: Maximal inspiratory and expiratory pressures in adolescents. Normal values. Chest, 1984, 86: 568-572. [Medline] [CrossRef]

5) Leech JA, Ghezzo H, Stevens D, et al.: Respiratory pressures and function in young adults. Am Rev Respir Dis, 1983, 128: 17-23. [Medline] [CrossRef]

6) Wilson SH, Cooke NT, Edwards RH, et al.: Predicted normal values for maximal respiratory pressures in caucasian adults and children. Thorax, 1984, 39: 535-538. [Medline] [CrossRef]

7) Domènech-Clar R, López-Andreu JA, Compte-Torrero L, et al.: Maximal static respiratory pressures in children and adolescents. Pediatr Pulmonol, 2003, 35: 126-132. [Medline] [CrossRef]

8) Delgado RN, Campos TF, Borja RO, et al.: Maximal respiratory pressures of healthy children: comparison between obtained and predicted values. Pediatr Phys Ther, 2015, 27: 31-37. [Medline] [CrossRef]

9) Heinzmann-Filho JP, Vasconcellos Vidal PC, Jones MH, et al.: Normal values for respiratory muscle strength in healthy preschoolers and school children. Respir Med, 2012, 106: 1639-1646. [Medline] [CrossRef]

10) Johan A, Chan CC, Chia HP, et al.: Maximal respiratory pressures in adult Chinese, Malays and Indians. Eur Respir J, 1997, 10: 2825-2828. [Medline] [CrossRef]

11) Masaki S, Teramoto S, Sudo E, et al.: Age-related changes static maximal inspiratory expiratory pressures. Nihon Kyobu Shikkan Gakkai Zasshi, 1997, 35: $1305-1311$.

12) Wagener JS, Hibbert ME, Landau LI: Maximal respiratory pressures in children. Am Rev Respir Dis, 1984, 129: 873-875. [Medline] [CrossRef]

13) Ministry of Health, Labour and Welfare: The National Health and Nutrition Survey in Japan, 2013, 08. http://www.mhlw.go.jp/bunya/kenkou/eiyou/d1/h25houkoku.pdf. (Accessed May 14, 2016)

14) Evans JA, Whitelaw WA: The assessment of maximal respiratory mouth pressures in adults. Respir Care, 2009, 54: 1348-1359. [Medline]

15) Zinman R, Gaultier C: Maximal static pressures and lung volumes in young female swimmers: one year follow-up. Pediatr Pulmonol, 1987, 3: 145-148. [Medline] [CrossRef]

16) Delgado RN, Campos TF, Borja RO, et al.: Maximal respiratory pressures of healthy children: comparison between obtained and predicted values. Pediatr Phys Ther, 2015, 27: 31-37. [Medline] [CrossRef] 